\title{
Influence of the Murine Diabetes Gene on Rubidium Ion Efflux from Perifused Islets
}

\author{
O. Berglund, J. Sehlin, and I.-B. Täljedal \\ Department of Histology, University of Umeå, Umeå, Sweden
}

Summary. Islets from diabetic C57BL/KsJ $d b / d b$ mice and normal C57BL/KsJ + / + mice were loaded with ${ }^{86} \mathrm{Rb}^{+}$and micro-perifused with nonradioactive medium for $25 \mathrm{~min}$. The appearance of ${ }^{86} \mathrm{Rb}^{+}$in the effluent could be described as the sum of two exponential functions with different proportionality constants. The rapid efflux component may have represented washout from the extracellular space, and had about the same proportionality constant in normal and diabetic mice. The slow efflux component probably reflected efflux across the islet cell plasma membranes. At $3 \mathrm{mmol} / \mathrm{l} \mathrm{D}$-glucose in the medium, the slow efflux was significantly retarded in diabetic as compared with normal mice. In normal mice, but not in diabetics, $20 \mathrm{mmol} / 1 \mathrm{D}$-glucose inhibited the slow efflux component. It is concluded that the basal $\mathrm{K}^{+}$permeability is decreased in $\mathrm{KsJ} d b / d b$ mouse islet cells, and that this abnormality may explain their persistant depolarization at low glucose concentrations.

Key words: $\beta$-cell, $d b$-gene, diabetic mice, glucose, $\mathrm{K}^{+}$-electrodiffusion, pancreatic islets, rubidium efflux.

$\mathrm{Rb}^{+}$flux measurements in the well-functioning islets of non-inbred $o b / o b$ mice led to the hypothesis that normal depolarization of $\beta$-cells, and insulin release, is dependent on a glucose-sensitive $\mathrm{K}^{+}$-electrodiffusion mechanism [1]; this hypothesis is supported by several subsequent studies [2-7].

The $\beta$-cells in diabetic C57BL/KsJ $d b / d b$ mice exhibit deficient insulin secretion $[8,9]$ and abnormal regulation of the membrane potential [10]. The insulin secretory defect in these mice was found to be associated with enhanced islet uptake of $\mathrm{Rb}^{+}$and defective glucose-sensitivity of $\mathrm{Rb}^{+}$retention [11].
Those results suggested the possibility that the diabetogenic defect could be explained in terms of an explicit hypothesis of normal $\beta$-cell function. However, the measurements of islet radioactivity in static incubations [11] could not settle the important question as to whether the basal $\mathrm{Rb}^{+}\left(\mathrm{K}^{+}\right)$permeability is decreased in $\mathrm{KsJ} d b / d b$ mice. We have therefore investigated the dynamics of ${ }^{86} \mathrm{R} 1$. .c $^{+}$efflux by perifusing islets and measuring the radioactivity appearing in the effluent.

\section{Materials and Methods}

\section{Animals}

Diabetic C57BL/KsJ $d b / d b$ mice, 27-36 weeks old (median 28 weeks) and of both sexes ( 5 males and 5 females), were taken from a local colony established with breeding couples from the Jackson Laboratories, Bar Harbor, Maine, USA. These mice were hyperglycaemic and obese [9], and as previously [11] were selected for study when a significant loss of body weight indicated that they had entered a phase of severe diabetes. Similarly aged $\mathrm{C} 57 \mathrm{BL} / \mathrm{KsJ}+1+$ mice without diabetes ( 6 males and 4 females) from the same colony were used as controls. Sex did not noticeably influence the results. All animals had free access to water and pelleted laboratory chow (Astra-Ewos, Södertälje, Sweden: Type R3) until about $18 \mathrm{~h}$ before killing. An earlier differential cell count on the islets in 7-8 month old animals revealed $81 \% \beta$-cells in the controls and $73 \% \beta$-cells in KsJ $d b / d b$ mice [8].

\section{Experimental}

Collagenase-isolated islets were incubated and perifused at $37^{\circ} \mathrm{C}$. The basal incubation medium had the same composition as KrebsRinger bicarbonate [12] except that the bicarbonate was replaced by $20 \mathrm{mmol} / \mathrm{l} 2-\left(N\right.$-hydroxyethyl-piperazine- $N^{n}$-yl $)$ ethanesulphonic acid (Hepes), pH 7.4, and the gas phase was ambient air. This buffer was chosen to ensure stability of pH even though the islets could not be kept in closed vials throughout. After preliminary incubation for $30 \mathrm{~min}$ in basal medium supplemented with $3 \mathrm{mmol} / 1 \mathrm{D}$-glucose and $0.5 \%(\mathrm{w} / \mathrm{v})$ bovine serum albumin, islets were incubated for $120 \mathrm{~min}$ in the same medium supplemented with $28 \mu \mathrm{mol} / 1{ }^{86} \mathrm{RbCl}(21 \mathrm{TBq} / \mathrm{mol})$. After brief washing in nonradioactive medium, $16-90$ islets were placed in a small $(30 \mu \mathrm{l})$ 


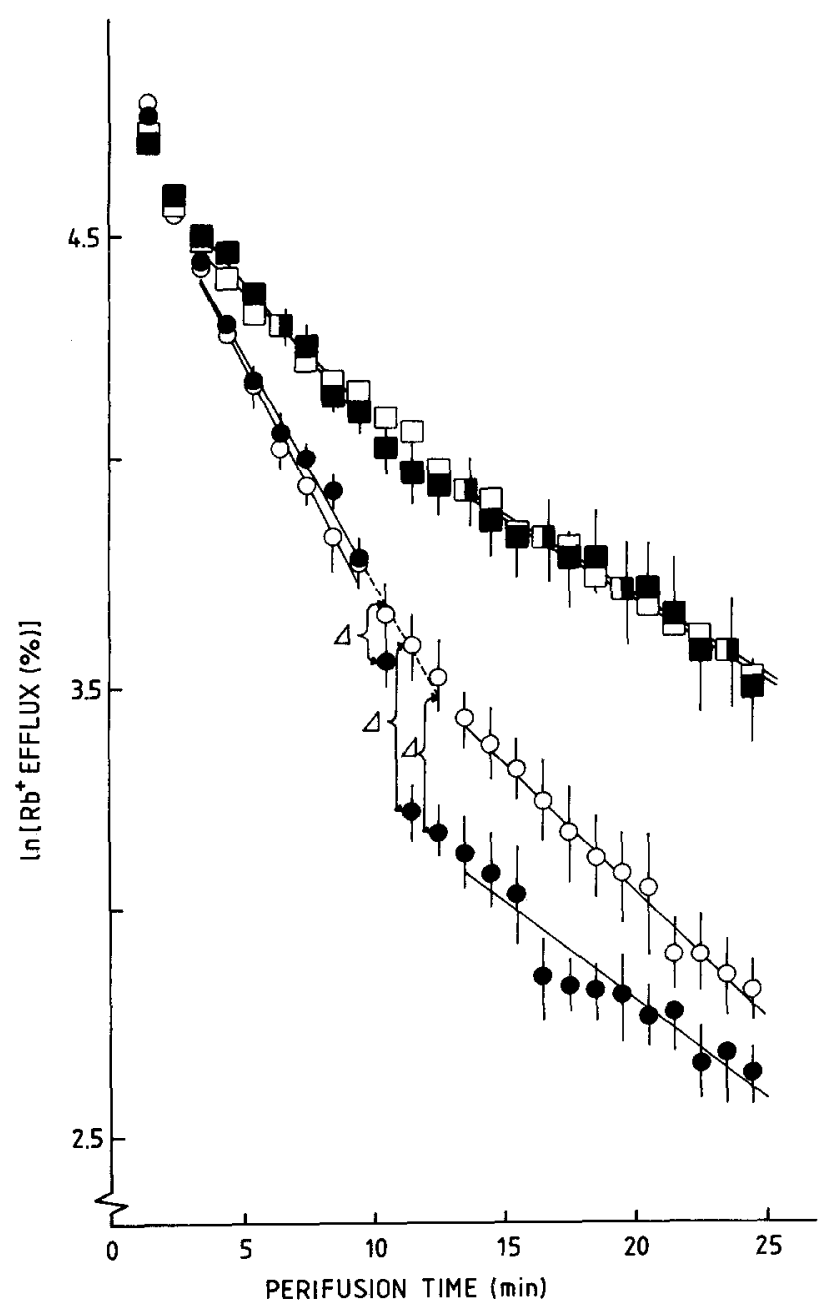

Fig. 1. Efflux of $\mathrm{Rb}^{+}$from islets of $\mathrm{KsJ}+1+$ mice $(\mathrm{O}, \bullet)$ and $\mathrm{KsJ}$ $d b / d b$ mice $(\square, \boldsymbol{\square})$ during perifusion with $3 \mathrm{mmol} / 1 \mathrm{D}$-glucose throughout $(O, \square)$ or when changing from 3 to $20 \mathrm{mmol} / 1 \mathrm{D}$ glucose after $10 \mathrm{~min}(\boldsymbol{\square}, \mathbf{\square})$. Efflux values in each experiment were calculated as percentages of the sum efflux in min 1.5-3.5; the ordinate shows the natural logarithms of these percentages. Mean values for $3(O, \square)$ and $7(\boldsymbol{\bullet}, \mathbf{D})$ separate experiments are shown. Vertical bars denote $\ln ($ mean \pm SEM $\%$ ). Solid lines were fitted by the method of least squares applied to the values in min 3.5-9.5, and $\min 13.5-24.5$ respectively. The dotted line and the delta symbols illustrate how the lines for $\min 3.5-9.5$ were extrapolated to $\mathrm{min} 12.5$ in order to calculate its deviation from values recorded after changing the glucose concentration

chamber in a perifusion apparatus sited in a thermostatically controlled incubator. One min after removing the islets from the ${ }^{86} \mathrm{RbCl}$ labelling medium perifusion was started. Non-radioactive basal medium containing $3 \mathrm{mmol} / 1 \mathrm{D}$-glucose and $0.5 \%(\mathrm{w} / \mathrm{v})$ serum albumin was pumped (Peristaltic pump P-3, Pharmacia, Uppsala, Sweden) through the chamber at a rate of $1.2 \mathrm{ml} / \mathrm{min}$. Fractions of effluent were collected over intervals of $1 \mathrm{~min}$. The supply of medium could be changed from one reservoir to another without interrupting the flow through the chamber. After $10 \mathrm{~min}$ the D-glucose concentration surrounding the islets was increased abruptly to $20 \mathrm{mmol} / \mathrm{l}$. The outlet from the chamber was so short that an immediate response of the islets to $20 \mathrm{mmol} / 1 \mathrm{D}$-glucose would be detectable within $1 \mathrm{~min}$.
After perifusion the islets were freeze-dried overnight $\left(-40^{\circ} \mathrm{C}, 0.1 \mathrm{~Pa}\right)$ and weighed on a quartz-fibre balance. They averaged $0.61 \mu \mathrm{g}$ from control mice (625 islets) and $1.39 \mu \mathrm{g}$ from diabetic mice ( 284 islets). The samples of effluent were analyzed for ${ }^{86} \mathrm{Rb}$ by liquid-scintillation counting. Samples of labelling medium were used as external standards in the counting procedure.

\section{Chemicals}

${ }^{86} \mathrm{RbCl}$ was from the Radiochemical Centre, Amersham, Bucks. UK. Bovine serum albumin (fraction 5) was from Sigma Chemical Co., St. Louis, MO, USA. Collagenase (CLS type IV) was from Worthington Biochemical Corp., Freehold, NJ, USA. Other reagents were of analytical grade.

\section{Results}

Earlier measurements of $\mathrm{Rb}^{+}$retention, $R$, by preloaded islets $[13,14]$ suggested that the efflux, $E$, of $\mathrm{Rb}^{+}$was a simple first-order process:

$E_{\mathrm{t}}=k R_{\mathrm{t}} ; \quad R_{\mathrm{t}}=R_{\mathrm{o}} e^{-k t}$.

However, the appearance of ${ }^{86} \mathrm{Rb}^{+}$in the effluent from perifused islets (Fig. 1) was not compatible with this simple model. When islets from normal or diabetic mice were perifused with $3 \mathrm{mmol} / \mathrm{l} \mathrm{D}$-glucose for $25 \mathrm{~min}$, a semilogarithmic plot of the data showed a conspicuous deviation from linearity. Similar results were obtained when perifusing non-inbred $o b / o b$ mouse islets in the same apparatus (not shown).

The derivative of the semi-logarithmic efflux function changes rapidly at the beginning of the experiments. When straight lines were fitted to different parts of the curves in individual experiments, the slope calculated in 3 experiments with $\mathrm{KsJ}+/+$ mice was $-0.110 \pm 0.010 \mathrm{~min}^{-1}$ in $\min 3.5-9.5$, $-0.060 \pm 0.007 \mathrm{~min}^{-1}$ in $\min 13.5-19.5$, and $-0.052 \pm 0.008 \mathrm{~min}^{-1}$ in min 19.5-24.5 (mean \pm SEM). The corresponding values in 3 experiments with $\mathrm{KsJ} d b / d b$ mice were $-0.057 \pm 0.000,-0.035$ \pm 0.003 , and $-0.040 \pm 0.006 \mathrm{~min}^{-1}$.

For efflux up to the 10th min, a total of 10 experiments were performed with $3 \mathrm{mmol} / 1 \mathrm{D}$-glucose in both control and diabetic mice. The straight line fitted to the data in min 3.5-9.5 had a significantly smaller slope ( $t$-test: $\mathrm{P}<0.001$; Wilcoxon: $\mathrm{P}<0.01$ ) in diabetic $\left(-0.065 \pm 0.003 \mathrm{~min}^{-1}\right)$ as compared with control $\left(-0.106 \pm 0.004 \mathrm{~min}^{-1} ;\right.$ mean \pm SEM $)$ mice. This difference in basal flux kinetics is a straight forward indicator of a real difference between control and diabetic mice. However, because of the complexity of the efflux curves, the slopes thus computed cannot be given a clear mechanistic interpretation. A two-compartment model, as simple as possible, was therefore tested in the further analy- 


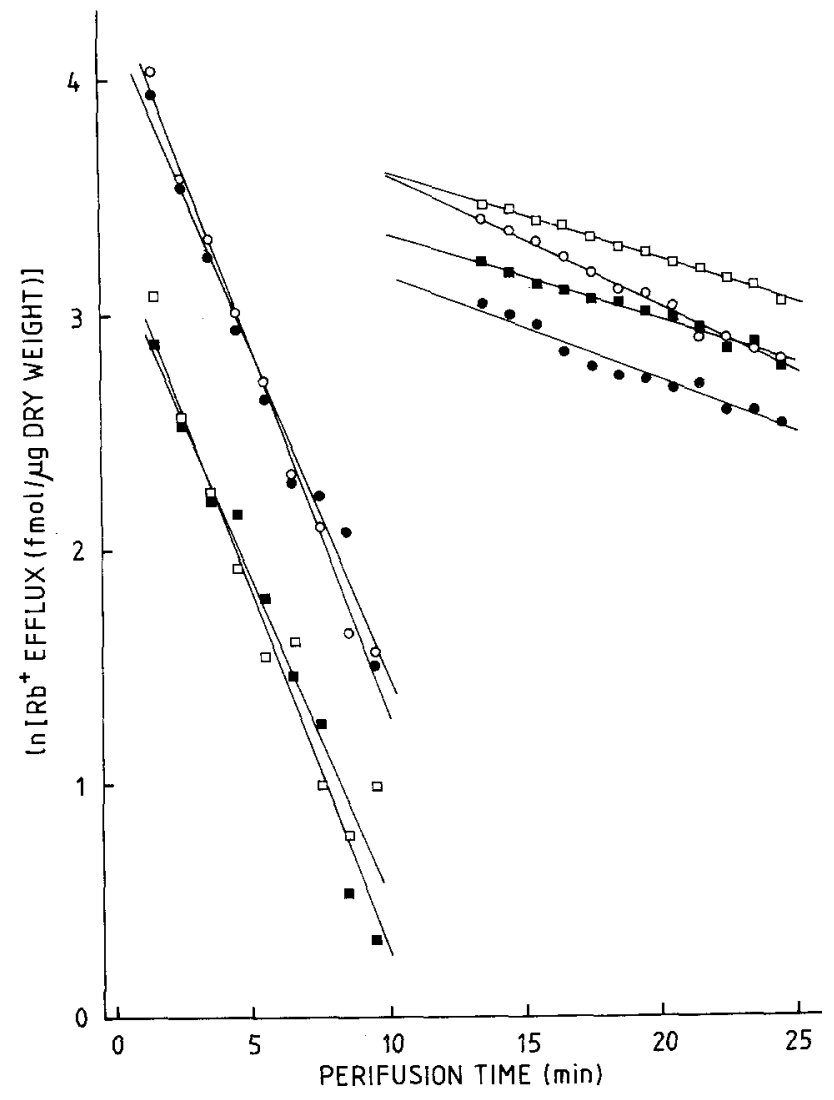

Fig. 2. Separation of efflux data into fast and slow components. Symbols are as in Figure 1. Whereas the values in min 13.5-24.5 are those actually recorded, the fast component was calculated by subtracting the slow efflux component as described in the text. This was done separately for each experiment except for KsJ + / + mice exposed to $20 \mathrm{mmol} / 1 \mathrm{D}$-glucose. When calculating the fast efflux component in that group of experiments, the mean values for the slow-efflux function parameters were used because of the abrupt shift of the curve induced by $20 \mathrm{mmol} / \mathrm{l} \mathrm{D}$-glucose. Lines are least-square fits to the indicated mean values

sis. The model assumes first-order efflux from two $\mathrm{Rb}^{+}$pools with different rate constants and initial values:

$E=k_{1} R_{1} e^{-k_{1} t}+k_{2} R_{2} e^{-k_{2} t}$

In each perifusion experiment the parameters of the slow pool were estimated by fitting a straight line to the logarithmically transformed efflux values in min 13.5-24.5. This line was extrapolated to zero time, and the explicit values for slow efflux obtained by antilog transformation at each time-point. By subtracting the calculated values from the radioactivity actually measured explicit values for the fast efflux component were obtained. Those values were finally transformed into logarithms and plotted. Figure 2 shows that the model fitted the data well. When the influence of the slow pool had been eliminated, the lines describing efflux from the fast pool (min $1.5-9.5)$ had about equal slope in control $(-0.317 \pm$
Table 1. Characteristics of $\mathrm{Rb}^{+}$efflux in min $13.5-24.5$ of perifusion. After logarithmic transformation of the $\mathrm{Rb}^{+}$efflux at each time-point, the coefficient for correlation with time $(r)$, the rate constant $(k)$, the half-life, and the pool size immediately after $120 \mathrm{~min}$ of loading (i.e. $1 \mathrm{~min}$ before perifusion) were calculated in each experiment. Mean values \pm SEM are shown for $3(3 \mathrm{mmol} / 1$ D-glucose) and 7 (20 mmol/l D-glucose) separate experiments

\begin{tabular}{|c|c|c|}
\hline Parameter & $\mathrm{KsJ}+/+$ & $\mathrm{Ks} \mathbf{J} d b / d b$ \\
\hline \multicolumn{3}{|l|}{$3 \mathrm{mmol} / \mathrm{l}$ D-glucose } \\
\hline$r$ & $-0.99 \pm 0.00$ & $-0.98 \pm 0.01$ \\
\hline$k\left(\min ^{-1}\right)$ & $-0.058 \pm 0.002$ & $-0.037 \pm 0.002^{a}$ \\
\hline Half-life (min) & $12.0 \pm 0.4$ & $18.9 \pm 1.0^{\mathrm{a}}$ \\
\hline 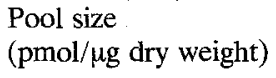 & $1.16 \pm 0.20$ & $1.46 \pm 0.11$ \\
\hline \multicolumn{3}{|l|}{$20 \mathrm{mmol} / \mathrm{l}$ D-glucose } \\
\hline$r$ & $-0.83 \pm 0.06$ & $-0.90 \pm 0.03$ \\
\hline$k\left(\min ^{-1}\right)$ & $-0.042 \pm 0.005$ & $-0.037 \pm 0.005$ \\
\hline Half-life (min) & $18.3 \pm 2.5$ & $20.7 \pm 3.1$ \\
\hline $\begin{array}{l}\text { Pool size } \\
\text { (pmol/ } / \mathrm{g} \text { dry weight) }\end{array}$ & $0.86 \pm 0.07$ & $1.18 \pm 0.20$ \\
\hline
\end{tabular}

${ }^{a} p<0.01$ for zero difference between types of mice (two-tailed $t$ )

$\left.0.008 \mathrm{~min}^{-1}\right)$ and diabetic $\left(-0.278 \pm 0.008 \mathrm{~min}^{-1}\right)$ mice (mean \pm SEM for 3 experiments with $3 \mathrm{mmol} / 1$ D-glucose throughout). The rate constants corresponded to a half-life of $2-2.5 \mathrm{~min}$.

Table 1 summarizes the characteristics of the slow efflux. In the presence of $3 \mathrm{mmol} / 1 \mathrm{D}$-glucose, the rate constant for diabetic mice was significantly smaller than that for controls. The corresponding halflives were about 6 times longer than those estimated for the fast efflux component. The pool size immediately after loading with $\mathrm{Rb}^{+}$(obtained by taking anti$\log$ ordinate at $t=-1 \mathrm{~min}$ and dividing by the slope of the fitted line) was similar in control and diabetic mice, with a non-significant tendency to higher values in the diabetics.

\section{Effects of Increasing the D-glucose Concentration}

In control mice, the sudden increase of D-glucose concentration from 3 to $20 \mathrm{mmol} / 1$ caused a rapid inhibition of $\mathrm{Rb}^{+}$efflux, as seen by the downward displacement of the efflux curve (Fig. 1). No such effect was observed in the diabetic animals. To test the significance of the D-glucose effect, the regression lines fitted to the efflux values in min 3.5-9.5 were extrapolated to min 12.5 (examplified by dotted line in Fig. 1). At min 10.5, 11.5, and 12.5, the vertical distance of this line from the values actually observed was calculated in each experiment for both types of mice. As can be seen in Figure 3, the effect of $20 \mathrm{mmol} / 1 \mathrm{D}$-glucose in the controls was significant already at $\min 10.5$, within the first minute after changing medium. In the diabetic mice no effect was found. 


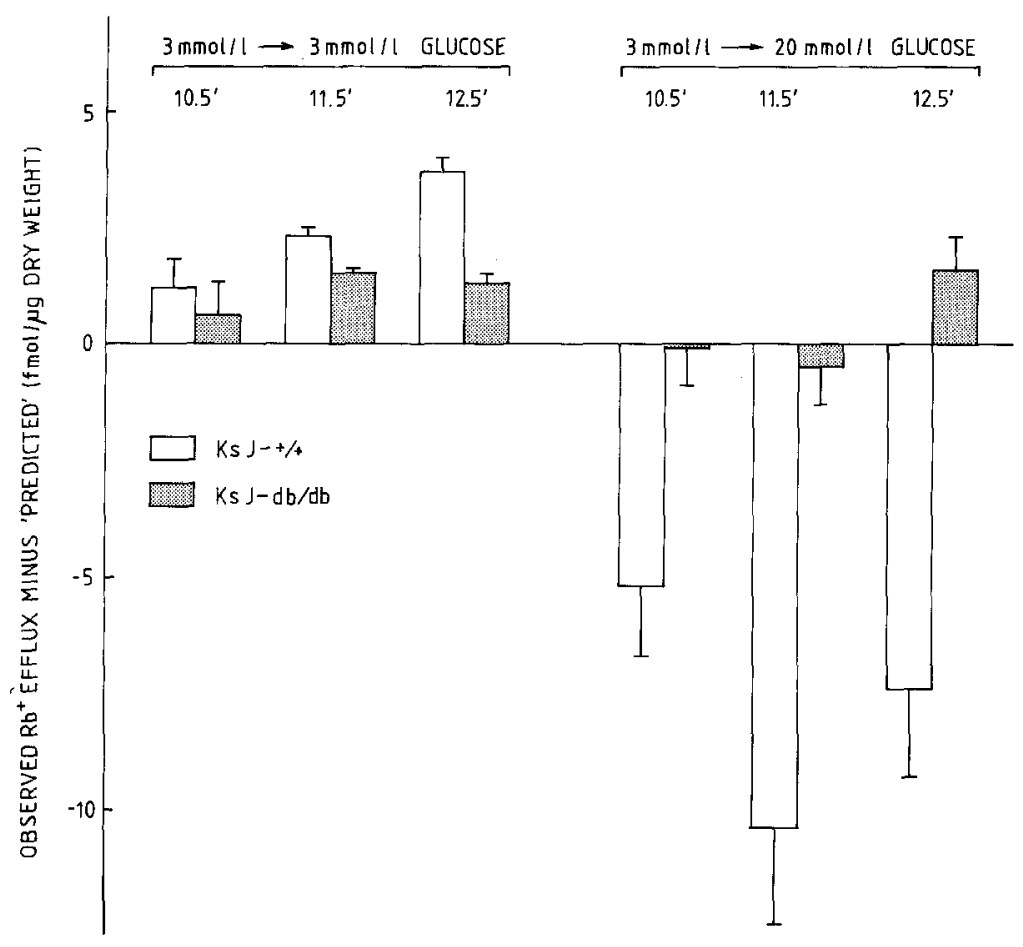

Fig. 3. D-Glucose-induced displacements of the efflux curve. The bars and vertical lines denote the differences (mean and SEM) between efflux values actually observed after $10.5,11.5$, and $\mathbf{1 2 . 5}$ min of perifusion on the one hand, and those calculated by extrapolating the straight lines fitted to data in min 3.5-9.5. For further explanation, see dotted line and delta signs in Figure 1. The negative values for $\mathrm{KsJ}+/+$ mice when changing from 3 to $20 \mathrm{mmol} / \mathrm{l}$ D-glucose are significant (two-tailed $t$ ) with $p<$ $0.02(\min 10.5)$ or $p<0.01(\min 11.5$ and 12.5$)$
When islets were perifused with $20 \mathrm{mmol} / \mathrm{l} \mathrm{D}$ glucose, the rate constant for the slow efflux component no longer differed significantly between control and diabetic mice (Table 1). Although D-glucose markedly altered the shape of the efflux curve in control animals (Fig. 1), the calculated size of the slow efflux pool at time zero was not changed (Table 1).

\section{Discussion}

The accumulation and retention of ${ }^{86} \mathrm{Rb}^{+}$by KsJ $d b /$ $d b$ mouse islets in static incubations have been described [11]. Although we have now used a different method in studying $\mathrm{Rb}^{+}$efflux by non-recirculating perifusion, the results of the two studies are consistent. Thus, by correcting for $\mathrm{Rb}^{+}$in the extracellular (sucrose) space of islets, the islet cell accumulation of $\mathrm{Rb}^{+}$in 120 min of static incubation with $28 \mu \mathrm{mol} / 1 \mathrm{RbCl}$ was calculated to be $0.73 \pm$ 0.10 (mean $\pm \mathrm{SEM}$ ) $\mathrm{mmol} / \mathrm{kg}$ dry weight for 22 controls, and $1.06 \pm 0.10 \mathrm{mmol} / \mathrm{kg}$ for 23 severely diabetic mice [11]. From the present curve for slow efflux, the intracellular Rl.c. ${ }^{+}$content after $120 \mathrm{~min}$ of loading with $28 \mu \mathrm{mol} / 1 \mathrm{RbCl}$ was estimated to be $0.99 \pm 0.09$ and $1.31 \pm 0.15 \mathrm{mmol} / \mathrm{kg}$ dry weight (mean \pm SEM for 10 control an 10 diabetic mice respectively). The ability of normal islets and the inability of diabetic mouse islets to increase $\mathrm{Rb}^{+}$retention in response to $20 \mathrm{mmol} / 1 \mathrm{D}$-glucose [11] are paralleled by the present dynamic data for the appearance of $\mathrm{Rb}^{+}$in the effluent. The inhibitory effect of glucose on $\mathrm{Rb}^{+}$and $\mathrm{K}^{+}$efflux from normal rat islets has been reported $[2,3,6]$.

Apart from consolidating previous conclusions concerning the glucose-insensitivity of islet $\mathrm{Rb}^{+}$ efflux in $\mathrm{Ks} \mathrm{J} d b / d b$ mice, the perifusion experiments extend past knowledge in one salient respect. Static incubations [11] could not settle the question as to whether the basal flux kinetics are altered in the diabetic mouse islet cells, but this question can now be given a clear affirmative answer. The basal efflux of $\mathrm{Rb}^{+}$was significantly retarded in the diabetic mouse islets, regardless of whether a statistical test was applied to the slopes of semi-logarithmic plots in min 3.5-9.5 (when efflux from the extracellular space probably compounded the data) or to the slope of such plots in min 13.5-24.5 (when transmembrane transport may have been the sole determinant of efflux kinetics).

It should be stressed that the mathematical model employed has deliberately been made as simple as is sufficient to fit the experimental data well within the random errors of the measurements. No attempt was made to resolve the slow efflux component into serially coupled fluxes between organelles and cytosol on the one hand and across the plasma membrane on the other; serial pools are mathematically more difficult to handle without necessarily giving a better fit to the experimental data. It is therefore theoretically conceivable that transport from an intracellular 'vacuolar system' [15] participated in 
regulating the slow efflux component. Similarly, the fast efflux may in reality comprise several phenomena, such as diffusion in the extracellular water, interaction with extracellular charged molecules, and desorption from cell surfaces. The most mobile portion of label is likely to have been removed already during the brief washing that preceded loading of the chambers. Therefore, although the estimated halflife of $2-2.5 \mathrm{~min}$ is longer than that reported for washout of extracellular $\mathrm{Na}^{+}$from perifused rat islets [15], it still appears compatible with a predominance of washout from the extracellular space and cell surfaces $[2,16,17]$.

As pointed out before [11] the difference in basal $\mathrm{Rb}^{+}$permeability between the two types of mice can help to explain why the diabetic mouse islets accumulated more $\mathrm{Rb}^{+}$than the control islets in static incubations, and probably also in the present study too, as indicated by the slow efflux kinetics (two-tailed $t$ : $\mathrm{P}<0.1$ for different pool size after $120 \mathrm{~min}$ of loading in 10 normal an 10 diabetic mice).

More important, the apparently low basal $\mathrm{Rb}^{+}$ permeability in diabetic mice is an abnormality that corroborates our hypothesis for normal $\beta$-cell depolarization by glucose-sensitive $\mathrm{K}^{+}$-electrodiffusion [1]. This is so because the hypothesis envisages that a reduction of $\mathrm{K}^{+}\left(\mathrm{Rb}^{+}\right)$permeability should lead to depolarization of the islet cells, and persistant depolarization at low glucose concentration has indeed been demonstrated in diabetic mouse $\beta$-cells [10]. This conclusion does not mean that altered $\mathrm{K}^{+}$ permeability is the only defect in the regulation of ionic fluxes and membrane electrical potential in $\mathrm{KsJ}$ $d b / d b$ mouse islet cells. The $\beta$-cell membrane potential may also depend on the $\mathrm{Cl}^{-}$permeability [18], which is increased in these diabetic mice (O. Berglund, J. Sehlin, unpublished work). The coupling of membrane depolarization to insulin release is likely to involve $\mathrm{Ca}^{2+}$ ions, and an abnormal efflux of ${ }^{45} \mathrm{Ca}^{2+}$ from KsJ $d b / d b$ mouse islets has been reported [19].

Acknowledgements. This work was supported by the Swedish Medical Research Council $(12 x-2288)$, the Swedish Diabetes Association, and the Clas Groschinsky Memorial Foundation.

\section{References}

1. Sehlin J, Täljedal I-B (1975) Glucose-induced decrease in $\mathrm{Rb}^{+}$permeability in pancreatic $\beta$-cells. Nature 253: 635-636

2. Henquin J-C (1977) Tetraethylammonium potentiation of insulin release and inhibition of rubidium efflux in pancreatic islets. Biochem Biophys Res Commun 77: 551-556

3. Henquin J-C (1978) D-Glucose inhibits potassium efflux from pancreatic islet cells. Nature 271: 271-273
4. Atwater I, Ribalet B, Rojas E (1979) Mouse pancreatic $\beta$ cells: tetraethylammonium blockage of the potassium permeability increase induced by depolarization. J Physiol (Lond) 288: $561-574$

5. Atwater I, Dawson CM, Ribalet B, Rojas E (1979) Potassium permeability activated by intracellular calcium ion concentration in the pancreatic $\beta$-cells. J Physiol (Lond) 288: 575-588

6. Malaisse WJ, Boschero AC, Kawazu S, Hutton JC (1978) The stimulus-secretion coupling of glucose-induced insulin release. XXVII. Effect of glucose on $\mathrm{K}^{+}$fluxes in isolated islets. Pfliigers Arch 373: 237-242

7. Henquin JC, Meissner HP (1978) Valinomycin inhibition of insulin release and alteration of the electrical properties of pancreatic $\beta$-cells. Biochim Biophys Acta 543: 455-464

8. Boquist L, Hellman B, Lernmark Å, Täljedal I-B (1974) Influence of the mutation "diabetes" on insulin release and islet morphology in mice of different genetic backgrounds. $\mathbf{J}$ Cell Biol 62: 77-89

9. Berglund O, Frankel BJ, Hellmann B (1978) Development of the insulin secretory defect in the genetically diabetic $(d b / d b)$ mouse. Acta Endocrinol (Kbh) 87: 543-551

10. Meissner HP, Schmidt H (1976) The electrical activity of pancreatic $\beta$-cells of diabetic mice. FEBS Lett $67: 371-374$

11. Berglund O, Sehlin J, Täljedal I-B (1978) ${ }^{86} \mathrm{Rb}^{+}$fluxes and $\mathrm{K}^{+}$-stimulated nitrophenyl phosphatase activity in the pancreatic islets of genetically diabetic mice (C57BL/KsJ $d b / d b$ ). Diabetologia 15: 191-195

12. De Luca HF, Cohen PP (1964) Suspending media for animal tissues. In: Umbreit WW, Burris RH, Stauffer JF (eds) Manometric techniques, 4th ed. Burgess Publishing, Minneapolis, p 131-133

13. Sehlin J, Täljedal I-B (1974) Transport of rubidium and sodium in pancreatic islets. J Physiol (Lond) 242; 505-515

14. Idahl L-Å, Lernmark $\AA$, Sehlin J, Täljedal I-B (1977) Alloxan cytotoxicity in vitro. Inhibition of rubidium ion pumping in pancreatic $\beta$-cells. Biochem J 162; 9-18

15. Kawazu S, Boschero AC, Delcroix C, Malaisse WJ (1978) The stimulus-secretion coupling of glucose-induced insulin release. XXVIII. Effect of glucose on $\mathrm{Na}^{+}$fluxes in isolated islets. Pflügers Arch 375: 197-206

16. Hellman B, Sehlin J, Täljedal I-B (1976) Effects of glucose on ${ }^{45} \mathrm{Ca}^{2+}$ uptake by pancreatic islets as studied with the lanthanum method. J Physiol (Lond) 254: 639-656

17. Frankel BJ, Imagawa WT, O'Connor MDL, Lundquist I, Kromhout JA, Fanska RE, Grodsky GM (1978) Glucosestimulated ${ }^{45}$ calcium efflux from isolated rat pancreatic islets. J Clin Invest 62: 525-531

18. Sehlin J (1978) Interrelationship between chloride fluxes in pancreatic islets and insulin release Am J Physiol 235: E501-E508

19. Hellman B, Andersson T, Berggren P-O, Flatt P, Gylfe E, Kohnert K-D (1979) The role of calcium in insulin secretion. In: Dumont $J$, Nunez $J$ (eds) Hormones and cell regulation, vol 3. Elsevier/North-Holland Biomedical Press, Amsterdam, p 69-96

Received: July 20, 1979,

and in revised form: February 1, 1980

Dr. Ove Berglund

Department of Histology

University of Umeå

S-90187 Umeå 6

Sweden 